\title{
MEANINGS AND PRACTICES OF ORAL HEALTH: A QUALITATIVE STUDY WITH MOTHERS OF DISABLED CHILDREN
}

\author{
SIGNIFICADOS E PRÁTICAS DE SAÚDE BUCAL: UM ESTUDO QUALITATIVO \\ COM MÃES DE CRIANÇAS COM DEFICIÊNCIA
}

\author{
Késia Lara dos Santos MARQUES ${ }^{1}$; Fabiana Sodré de OLIVEIRA²; \\ Larisse Paula de OLIVEIRA ${ }^{3}$; Natália Martins JOAQUIMª ; Guilherme Silva MENDONÇA ${ }^{5}$; \\ Alessandra Maia de CASTRO ${ }^{2}$ \\ 1. Doutoranda em Odontologia, Programa de Pós-graduação em Odontologia, Faculdade de Odontologia da Universidade Federal de \\ Uberlândia, Uberlândia, Minas Gerais, Brasil; 2. Professora da Área de Odontologia Pediátrica, Faculdade de Odontologia da \\ Universidade Federal de Uberlândia, Uberlândia, Minas Gerais, Brasil; 3. Cirurgiã-dentista, Faculdade de Odontologia da Universidade \\ Federal de Uberlândia, Uberlândia, Minas Gerais, Brasil; 4. Residente do Programa Atenção integral ao paciente com necessidades \\ especiais, Faculdade de Medicina da Universidade Federal de Uberlândia, Uberlândia, Minas Gerais, Brasil; 5. Doutorando em Ciências \\ da Saúde pela Universidade Federal de Uberlândia. Enfermeiro. Hospital de Clínicas de Uberlândia da Universidade Federal de \\ Uberlândia, Uberlândia, Minas Gerais, Brasil.
}

\begin{abstract}
The aim of this study was to understand the meanings and oral health practices of ten mothers of disabled children between the ages of zero and three years. The qualitative method was used. The data was collected by means of a semi-structured interview and were recorded, transcribed and analysed using the Thematic Content Analysis. Regarding to the oral health care of the mothers, three reported difficult and traumatising experiences and three did not have much contact with dentists during their childhood. Regarding to the children, the age of their first visit to the dentist varied from three months to two years and six months, and the reason for this appointment for seven children was referral by their doctor or by the Association of Parents and Friends of the Exceptional. Seven mothers reported that they brushed the teeth of their children at least twice a day and only two cited the importance of regular dental appointments. For two mothers, the meaning of oral health was to have a perfect smile and for four others, maintain oral hygiene. Half of the mothers related oral health to general health. All reported that dental caries is related to diet and lack of care regarding to oral hygiene. It was possible to conclude that for this group of mothers, oral health has an important meaning and that oral health practices are based on a healthy diet and brushing. Although mothers of disabled children have presented positive attitudes, in general, the results indicated limited knowledge about oral health. The results showed the importance of considering the point of view of the mothers as data of analysis bringing greater proximity with the reality studied. More qualitative studies should be conducted in order to collaborate with the improvement of the oral condition of disabled children.
\end{abstract}

KEYWORDS: Oral Health. Mothers. Disabled Children. Qualitative Research.

\section{INTRODUCTION}

Currently, the term used to refer to patients with special needs is "People with Disabilities", which are those that have long-term impairments of a physical, mental, intellectual or sensorial nature, which in interaction with different obstacles, can impede their full and effective participation in society under equal conditions (ONU, 2006).

Data from the Brazilian Institute for Geography and Statistics show that 45.6 million people have some type of impairment, equating to $23.91 \%$ of the population of Brazil. In the 0 to 14 age group, this number equates to 3.459 .401 people (OLIVEIRA, 2012).

Numerous studies have shown that disabled children suffer from a higher dental caries rate, when compared to the population in general (DOS
SANTOS; MASIERO; SIMIONATO, 2002; RODRIGUES DOS SANTOS et al., 2003; OREDUGBA; AKINDAYOMI, 2008; GRACE; KELMEND; FUSHA, 2014; LIU et al., 2014; SINHA et al., 2015). The study by Gaçe, Kelmender and Fusha (2014) examined prevalence of dental caries and oral health condition in children and adolescents with varying disabilities between the ages of zero and 18 years. The results showed that the prevalence of dental caries in permanent dentition for all groups was of $85.3 \%$, and $72.0 \%$ for primary dentition, also demonstrating poor oral hygiene.

Even though disabled children are considered a high risk group in regard to dental caries (VOZZA et al., 2016) and have a greater need for dental treatment as well as their parents and caregivers attention (GRACE; KELMENDI; 
FUSHA, 2014), in fact only a few receive early, preventive dental care (HUEBNER et al., 2015).

The centres that offer dental care for disabled children between the ages of zero and three years provide an excellent opportunity for monitoring the oral health of these patients, as well as providing resources and information for the parents concerning the effective prevention of dental caries and assisting them in stablishing the necessary oral health measures at home (ONU, 2006). These measures are fundamental for preserving the integrity of the individual and consequently influence the general state of health (COSTA; DELLA BONA; TRENTIN, 2016).

Regarding to oral health, the awareness by health professionals of the reality of their patients allows for an approach that is more tailored to their needs. This understanding can be strengthened by qualitative studies (ROBLES; GROSSEMAN; BOSCO, 2010). Considering that the number of disabled children with demand dental care has increased due to the improvement in the expectation and quality of life, dental caries is the need for more prevalent unmet health care (LIU et al., 2014) and that in the literature consulted few qualitative studies on the subject were performed, it is justified to carry out studies of this nature with this specific population. As such, the present qualitative study was carried out with the objective of understanding the oral health meanings and practices of mothers of disabled children between zero and three years of age treated at the clinic of Pediatric Dentistry of the School of Dentistry of the Federal University of Uberlândia. It was assumed that for the mothers of disabled children, oral health has an important meaning and contribute to general health, but that they find difficulties in performing oral hygiene practices.

\section{MATERIAL AND METHODS}

The outline of the study was based on the qualitative method of Thematic Content Analysis (MINAYO, 2014), with convenience sampling being used. It was developed in consultation with ten mothers of disabled children of both sexes aged between zero and three years and treated at the clinic for disabled children, at the Dental Hospital of the Federal University of Uberlândia. The study included mothers of children with any type of disability (intellectual, physical, visual, hearing or multiple) aged less than or equal to three-year-old attended in clinics of pediatric dentistry in the first semester of 2016 who agree to participate.
First contact was conducted with the mothers in the waiting room, for the introduction of the researchers. After clarifications, explanation of the objectives and methods of the study, and making clear the possibility of dropping out of the study at any moment, the mothers were invited to participate in the research. After their consent, their signing of two copies of the Free and Informed Consent Form was requested. All the invited mothers agreed to participate in the study.

The data was collected via questionnaire by means of a semi-structured interview. The guiding questions were: 1 . how were your experiences with dentists throughout your life? 2. nowadays, how do you take care of your teeth? 3. how do you take care of your children's teeth? 4. what is oral health for you? 5. what is the importance of oral health for the general health of your child? 6. why do you think the teeth spoil? 7. why did you seek the university clinic? 8. what have you learned about mouth care since children started treatment at the UFU School of Dentistry? (ROBLES, 2005). To maintain anonymity, the mothers were denominated as M1, M2, M3, M4, M5, M6, M7, M8, M9 and M10.

The interviews were performed individually in a reserved room, with the intent of avoiding possible embarrassments on the part of the mothers by a previously calibrated researcher (undergraduate student and female). The researcher who performed the interviews had no connection with the research participants, but also no previous knowledge, clinical or superiority relationship. The interviews were recorded, transcribed and analysed, with their consent. After being transcribed, the recordings were deleted.

Before the data collection step, a pre-test of the instrument was performed. The instrument was applied by a single researcher in interview form to two mothers selected randomly who were in a reserved waiting room. In those case where the questions were unclear, these were reformulated. The reformulation of the questions was not necessary, and these interviews were not used in the research. The interviews were held only once. Although the study script was not changed, the two pilot interviews were excluded because they were performed for calibration of the researcher and, therefore, were not considered in the research.

For descriptive analysis, the following variables were considered: in relation to the mother: sociodemographic and socioeconomic data (age: in complete years, at the date of the interview; marital status: married, single or widow; level of education; amount of children and their age; out-of-home work and family income); in relation to the children: age 
(as of the date of the interview); sex; child position; age at which they started treatment at the institution; motives for the appointment; classification of the child regarding to their impairment according to Santos and Sabbagh-Haddad (2003).

The data were analysed by the Thematic Content Analysis (MINAYO, 2014; FLICK, 2019) with the objective of understanding the importance of oral health in the context of general health from the point of view of mothers of disabled children, considering from the mother's history of oral health past and present until the practices adopted in their children. Thematic analysis was performed in three stages. In the first step (Pre-analysis), initially, the transcriptions of the interviews were fully read. Then, the registration unit (keyword), the context unit (the delimitation of the context of understanding the registration unit), the cutouts, categorization form, the encoding modality and the more general theorical concepts that guided the analysis were determined. Keywords and excerpts considered important to answer questions about the theme were highlighted in the text. In the second stage, the material was explored, consisting essentially of a classification operation in order to reach the nucleus of understanding the text. For this, the researcher sought to find categories (expressions or significant words) according to which the content of a speech will be organized. In the third and last stage, the results were obtained, and the interpretation were performed. The data were evaluated manually.

The research protocol was submitted for assessment to the Ethics in Research Committee of the Federal University of Uberlândia and approved under Certificate of Presentation for Ethical Appreciation number 45529515.9.0000.5152 and Opinion no 1.227.704.

\section{RESULTS}

\section{Profile of the mothers and children}

Table 1 shows the variables studied concerning the mothers. The age of the mothers varied between 22 and 40 years, with an average age of 29 years and two months. Eight mothers were married and five had completed secondary education. Seven mothers had two children aged between three months and six years. Only two mothers where employed, and household income varied between one to three minimum salaries.

Table 1. Profile of the interviewed mothers.

\begin{tabular}{|c|c|c|c|c|c|c|c|}
\hline Mother & $\begin{array}{c}\text { Age } \\
\text { (years) }\end{array}$ & $\begin{array}{c}\text { Marital } \\
\text { status }\end{array}$ & Level of education & $\begin{array}{l}\text { No of } \\
\text { Children }\end{array}$ & $\begin{array}{l}\text { Children } \\
\text { Age }\end{array}$ & Working & $\begin{array}{c}\text { Household } \\
\text { Income }\end{array}$ \\
\hline M1 & 25 & Single & $\begin{array}{c}\text { Secondary Education } \\
\text { Complete }\end{array}$ & 2 & $\begin{array}{c}2 \text { and } 6 \\
\text { years }\end{array}$ & No & 1 salary \\
\hline M2 & 22 & Single & $\begin{array}{l}\text { Secondary Education } \\
\text { Incomplete }\end{array}$ & 1 & 1 year & No & 1 salary \\
\hline M3 & 29 & Married & $\begin{array}{l}\text { Secondary Education } \\
\text { Complete }\end{array}$ & 1 & 9 months & No & 1 salary \\
\hline M4 & 22 & Married & $\begin{array}{c}\text { Secondary Education } \\
\text { Complete }\end{array}$ & 1 & 1 year & No & 1.5 salary \\
\hline M5 & 29 & Married & $\begin{array}{l}\text { Higher Education } \\
\text { Complete }\end{array}$ & 2 & $\begin{array}{l}9 \text { months } \\
\text { and } 5 \\
\text { years }\end{array}$ & No & 1 salary \\
\hline M6 & 25 & Married & $\begin{array}{c}\text { Secondary Education } \\
\text { Complete }\end{array}$ & 2 & $\begin{array}{c}2 \text { and } 6 \\
\text { years }\end{array}$ & No & 3 salaries \\
\hline M7 & 39 & Married & $\begin{array}{l}\text { Higher Education } \\
\text { Complete }\end{array}$ & 2 & $\begin{array}{c}1 \text { and } 6 \\
\text { years }\end{array}$ & Yes & 3 salaries \\
\hline M8 & 32 & Married & $\begin{array}{c}\text { Secondary Education } \\
\text { Complete }\end{array}$ & 2 & 3 months & No & 1 salary \\
\hline M9 & 29 & Married & $\begin{array}{l}\text { Higher Education } \\
\text { Complete }\end{array}$ & 2 & $\begin{array}{c}1 \text { and } 5 \\
\text { years }\end{array}$ & Yes & 3 salaries \\
\hline M10 & 40 & Married & $\begin{array}{c}\text { Secondary Education } \\
\text { Complete }\end{array}$ & 2 & $\begin{array}{c}2 \text { and } 5 \\
\text { years }\end{array}$ & No & 1 salary \\
\hline
\end{tabular}


Table 2 shows the variables studied concerning the children. The age of the children varied between nine months and two years and ten months, with an average age of 20.4 months. Seven were male and second child. The age of the children when they first started treatment at the institution varied between three and 30 months, with an average age of 12.8 months. The motive for the appointment was the routine check-up for six children, medical referral for three children, and due to difficulties in brushing teeth and bruxism for one of the children. In relation to classification, eight children were included in the Syndromes and craniofacial deformities category, with seven presenting Down Syndrome and one child with translocation of chromosomes 3 and 7. Only one child was classified as having physical impairment, due to imperfect osteogenesis. One of the children had not yet received a definitive diagnosis and was undergoing analysis.

Table 2. Child profile.

\begin{tabular}{|c|c|c|c|c|c|c|}
\hline Mother & Age & Sex & $\begin{array}{l}\text { Family } \\
\text { position }\end{array}$ & $\begin{array}{c}\text { Age of the } \\
\text { beginning of } \\
\text { dental } \\
\text { treatment }\end{array}$ & $\begin{array}{l}\text { Appointment } \\
\text { motive }\end{array}$ & Classification \\
\hline M1 & $\begin{array}{l}2 \text { years } \\
\text { and } 5 \\
\text { months }\end{array}$ & Female & $2^{\text {nd }}$ child & $\begin{array}{c}2 \text { years and } 5 \\
\text { months }\end{array}$ & Routine check-up & Undergoing analysis \\
\hline M2 & $\begin{array}{l}1 \text { year } \\
\text { and } 7 \\
\text { months }\end{array}$ & Female & $1^{\text {st }}$ child & $\begin{array}{l}1 \text { year and } 7 \\
\text { months }\end{array}$ & $\begin{array}{l}\text { Difficulties in } \\
\text { brushing teeth and } \\
\text { bruxism }\end{array}$ & Down Syndrome \\
\hline M3 & $\begin{array}{c}9 \\
\text { months }\end{array}$ & Male & $1^{\text {st }}$ child & 9 months & Medical referral & Down Syndrome \\
\hline M4 & $\begin{array}{l}1 \text { year } \\
\text { and } 6 \\
\text { months }\end{array}$ & Male & $1^{\text {st }}$ child & $\begin{array}{c}1 \text { year and } 6 \\
\text { months }\end{array}$ & Routine check-up & Down Syndrome \\
\hline M5 & $\begin{array}{c}9 \\
\text { months }\end{array}$ & Male & $2^{\text {nd }}$ child & 9 months & Medical referral & Down Syndrome \\
\hline M6 & $\begin{array}{l}2 \text { years } \\
\text { and } 7 \\
\text { months }\end{array}$ & Male & $2^{\text {nd }}$ child & 3 months & Medical referral & $\begin{array}{c}\text { Translocation of } \\
\text { chromosomes } 3 \text { and } 7\end{array}$ \\
\hline M7 & $\begin{array}{l}1 \text { year } \\
\text { and } 1 \\
\text { month }\end{array}$ & Male & $2^{\text {nd }}$ child & 9 months & Routine check-up & Down Syndrome \\
\hline M8 & $\begin{array}{l}2 \text { years } \\
\text { and } 6 \\
\text { months }\end{array}$ & Male & $2^{\text {nd }}$ child & 3 months & Routine check-up & Imperfect Osteogenesis \\
\hline M9 & $\begin{array}{l}1 \text { year } \\
2 \text { vears }\end{array}$ & Female & $2^{\text {nd }}$ child & 6 months & Routine check-up & Down Syndrome \\
\hline M10 & $\begin{array}{l}\text { and } 10 \\
\text { months }\end{array}$ & Male & $2^{\text {nd }}$ child & 5 months & Routine check-up & Down Syndrome \\
\hline
\end{tabular}

\section{Understanding the past and present history of} the oral health of the mothers

Regarding to their experiences with dentists during childhood, three mothers (M2, M7 and M9) reported that they were traumatising. "At the beginning it was difficult, when I was a child. My mother would take me..." (M7). Another three (M1, M4, and M8) said they did not have much contact with dentists throughout their lives: "I, particularly, did not have much experience with [dentists], I went very little" (M8).
Regarding to oral health care, six mothers said they brush their teeth every day, with a frequency of two to four times a day. Only one of the mothers (M2) reported that dental floss was only used when possible: "I brush my teeth every day, at least three times a day, but I floss only when I have time". Six of the mothers did not report the use of dental floss.

Only one of the mothers (M8) indicated the avoidance of sugar because she knew of the impact it can have on dental health. 
With regard to past dental history, some mothers reported that they did not have much contact with the dentist as a child. Those who remembered their experiences with dental treatment reported that they had been good, difficult or traumatizing. One participant cited the mother's role in caring for oral health. Many participants reported that they currently maintained regular dental followup. It was possible to observe that most mothers maintained good oral health habits, although they did not use dental floss, which demonstrates their importance in relation to oral hygiene. However, most mothers do not consider the effect of sucrose consumption on oral health.

\section{Understanding the oral health background of the disabled children}

\section{the children}

Care taken in regard to the oral health of

When asked about the manner in which they took care of the oral health of their children, half of the interviewed mothers indicated the performance of oral hygiene by means of daily brushing. M2 reported difficulties in brushing the teeth of her child: "I brush only two times a day because the child will not let me". M10 reported the use of dental floss when possible.

M4 said she did not receive any orientation, and so does not perform the oral cleaning of her child. "I am still not taking care in such a way because he only has two teeth at the moment. I have not yet received any orientation".

The use of a cloth and filtered, warm water for the cleaning of the gum flanges was reported by M3. "As he is still a baby, I use a cloth soaked in warm filtered water to remove residues from the gum flanges and avoid bad breath".

M5 and M7 remembered the importance of taking the children to the dentist regularly. Control over cariogenic food was also emphasised: "attempt to eat less sugar to avoid cavities" (M5) and "I don't give them a lot of sweets, lollipops, these sweet things that are harmful, fizzy drinks..." (M8).

M9 commented that she gives her child the attention she did not receive during her childhood. She does not blame her mother, but their precarious situation. "I try to provide the best care possible, the type I did not have during my childhood... well, it was not my mother's fault... well, in the city I lived, dentists were very unreliable because they had to come from outside, so there were very few dentists. With my children, I'm a lot more attentive".

For all mothers, oral hygiene represents the most important practice related to oral health, although it is difficult to be performed. The use of the floss was neglected by the majority. In addition, the practice of oral hygiene was performed according to the absence or presence of teeth. Mothers recognize the importance of good dietary habits as well as periodic care. It is possible to identify that they did not have the same opportunity to receive dental treatment when they were children.

\section{The meanings attributed to oral health}

M10 highlighted the importance of having a healthy mouth, especially in the case of her disabled child.

On the whole, "lack of care" was the main motive pointed out by the mothers for tooth decay. For some, dental caries is associated with a sugarrich diet, unsatisfactory cleaning and the presence of bacteria. According to M7, "through the mouth, you can acquire many bacteria".

Even though she had no knowledge concerning the factors relating to the etiology of the disease, M9 reported: "well, there is a physical, genetic question, but I believe that the lack of care is the problem".

Other factors mentioned as the cause of tooth decay were a sugar-rich diet, the lack of nighttime brushing, and the lack of regular check-up with the dental surgeon: "Lack of care, lack of brushing, eating a lot of sweets and not going to the dentist regularly" (M7); “... due to the diet as well, sweets, fizzy drinks, biscuits, these sweet things that damage the children's teeth" (M8); “... eating sweets, going to bed without brushing" (M10).

Regarding to the meaning of oral health, the interviewed mothers were unanimous in saying that it means hygiene, care and health, health in a general sense.

\section{The search for dental treatment at the university}

Among the motives behind the decision of the interviewed mothers to look for a university clinic, the care available for the specific needs of their children, medical suggestion and/or referral, and their financial situation are points emphasised. Nonetheless, M9 said: "As I have already been doing medical follow-ups here since 2007 and trust it highly, I believe a lot in the professionals here. I follow all their instructions, so for me, this place is everything. I have a health plan, but I prefer it here".

\section{Learning about oral health care}

In relation to the knowledge acquired about oral care during treatment at the institution, some points were generally reported: greater attention to mouth and teeth, daily brushing, use of dental floss, night-time brushing, having regular dentist 
appointments, pay attention to the consumption of sweet foods, the relationship between the nightly feeding bottle and tooth cavities, and the importance of cleaning the oral cavity for children with special needs. An account by M9: "Look, I have learned, as they say, a lot. But to have this kind of care, this attention, it's... like they say, pay more attention to sweet foods, take care with sweets... especially before bed time, brush these teeth, check how the teeth are, this stricter care...well, for me, this was very enlightening".

\section{DISCUSSION}

The main objective of the present qualitative study was to understand the oral health meanings and practices of mothers with disabled children. The qualitative research answers very particular questions. It deals, in Social Science, with a level of reality that cannot or should not be quantified. In other words, it deals with the universe of meanings, motives, aspirations, beliefs, values and attitudes. This range of human phenomena is understood here as part of social reality, given that human beings distinguish themselves not solely by their capacity for action, but by also reflecting about what they do and by interpreting their actions from within and based on their lived and shared reality. Thus, the difference between the quantitative and qualitative approaches of social reality is a natural one, and not one of hierarchic ranking (MINAYO, 2010).

The methodology used in the present study followed the same as that used by Robles, Grosseman and Bosco (2010). These authors evaluated the practices and meanings of oral health in non-disabled children between the ages of three and ten years, treated at the Federal University of Santa Catarina. Only some guiding questions were added in the present study, directed to the selected public.

The family is the basis for the social, psychological and emotional development of the child and is the environment in which basic care is administered to the body, playing a fundamental role in promoting and maintaining its health (AGOSTINI et al., 2014; OREDUGBA; AKINDAYOMI, 2008). The mother was chosen because she has a key role in the family (MARCELINO; PARRILHA, 2007). Generally, it is responsible for the issues involving health, exercising the role of forming knowledge and habits (FIGUEIRA; LEITE, 2008).

Working with the assumption that an ideal sample is that which is capable of reflecting its population within its dimensions, the sample size was based on the saturation that considers the number of sufficient subjects when a certain repetition of information is allowed, but disregards unusual information of which explicative potential must be considered (MINAYO, 2010). Therefore, for this study ten mothers of disabled children between the ages of zero and three years were selected. In other qualitative studies (ROBLES; GROSSEMAN; BOSCO, 2010; DOMINGUES; CARVALHO; NARVAI, 2008; OLIVEIRA et al., 2010; SIMIONI; COMIOTTO; REGO, 2005), seven mothers were selected, ten mothers (DOMINGUES; CARVALHO; NARVAI, 2008), nineteen mothers (OLIVEIRA et al., 2010) and twenty mothers (SIMIONI; COMIOTTO; REGO, 2005).

No similar studies were found for a direct comparison of the results. In the literature consulted, only one qualitative study was found (OLIVEIRA et al., 2010) about the perception of parents in oral health of mothers of disabled children. Oliveira et al. (2010) investigated the perceptions of a group of mothers of children and adolescents with Down syndrome regarding the general health and oral health of their children. The results showed that for mothers, general and oral health are mainly associated with the absence of disease, the performance of daily activities and feelings of wellbeing. The authors concluded that factors related to financial difficulties, time and access to health referral services hinder the search for specialized dental care for disabled children and adolescents. In the present study, no mother reported financial difficulty or access to the service for dental treatment. Even, a mother reported that she had a dental agreement, but she preferred to be attended in the public service by indication of the physician accompanying the child.

It was possible to compare the results obtained in qualitative research with children without disabilities. Although the research of Robles, Grosseman and Bosco (2010) was performed with mothers of non-disabled children older than three years, there were observable similarities between the answers obtained. This is probably because the study was conducted in clinics of public institutions in which the assisted population usually presents low socioeconomic and educational levels. This is evident when comparing the responses obtained.

While some of the interviewed subjects reported that their experiences with dentists throughout their lives were traumatising, unpleasant or bad, just the same as all interviewees in the study of Robles, Grosseman and Bosco (2010), others in the present study did not have much contact with 
dentists due to the precariousness of their life conditions. People who do not have periodic followup with the dentist, it is very common to perform invasive and complex dental treatments, such as endodontics and surgical ones, which justifies the report of negative experience.

The majority of the interviewed mothers reported the performance of daily brushing, as well as striving for regular dental treatment, differing from the study of Robles, Grosseman and Bosco (2010), where the interviewed mothers looked for treatment only when necessary. This difference could be related to the fact that in the present study, half of the mothers reported that oral health is very important for health in general and, for that reason, the search for treatment was for disease prevention and not just for treating a particular complication. It was observed a concern of the mothers regarding the oral health and their relationship with general health in agreement with another studies (OLIVEIRA et al., 2010; ROBLES; GROSSEMAN E BOSCO, 2010).

Regarding the oral hygiene of their children, as in another qualitative study with disabled children mothers tend to remain responsible for the health of their children, but many have reported difficulties in caring for their children's oral health (OLIVEIRA et al., 2010). Only one reported the use of dental floss only when possible. This data agrees with another quantitative study, the results showed that $80 \%$ of the parents do not use dental floss in the oral hygiene of people with disabilities (SOARES et al., 2013). Usually, it is very difficult to perform tooth brushing in disabled children due to behavior and also the presence of involuntary movements. The use of dental floss is still more difficult which justifies the results obtained.

The use of a cloth with warm water to clean the gum flanges of the children that did not yet have teeth was also registered, similarly to the mothers in the study of Robles, Grosseman and Bosco (2010). Cultural, social and economic factors contribute to daily brushing being the most adopted preventive measure. Oral cleaning has been recommended to all individuals, being considered an important requirement for social acceptance. The motives that lead people to perform oral cleaning are related to their wish of having a pleasant-smelling breath, of looking good, of feeling comfortable and being socially accepted (FIGUEIRA; LEITE, 2008).

Those participating in the research pointed out that the working hours, lack of time and difficulties with the cleaning process due to the impairment of their children all impacted in the care of child oral health.
During the interview with the mothers, we noted the value they attribute to brushing after meals, noting as well that they have a notion of the controls that one should have over cariogenic diets (especially in regard to sweets). Similar results were found in other studies (ROBLES; GROSSEMAN; BOSCO, 2010; SIMIONI; COMIOTTO; REGO, 2005). In the present study, one of the mothers reported paying greater attention to the oral health of her children compared to that received during her childhood. This is partly due to the fact that the child has a disability and the mother has been oriented about the importance of care by health professionals.

It was noted in the present study that the mothers had difficulties in conceptualising oral health, similarly to the other studies (ROBLES; GROSSEMAN; BOSCO, 2010; DOMINGUES; CARVALHO; NARVAI, 2008) with mothers of disabled children. For the mothers analysed, oral health is related to habits of oral hygiene and diet as well as visiting the dentist, where the concern is placed more upon aesthetics, and little in terms of functionality (DOMINGUES; CARVALHO; NARVAI, 2008).

The results of this qualitative study are also in accordance with those observed in other studies (ALYAHYA, 2016; KUMAR et al., 2019) with different methodology (cross-sectional study) with non-disabled children in which parents showed limited to good knowledge and practice with regard to their children's oral health and positive attitude regarding the importance of role in theirs children's daily oral hygiene. Although, the authors (KUMAR et al., 2019) found good results about parental awareness and attitudes regarding their children's oral health, the dental caries prevalence was high contradicting the results. Other author (ALYAHYA, 2016) concluded that for non-disabled children, coordinated efforts by health professionals, including paediatric dentists and paediatricians are required to increased parental awareness regarding feeding and oral health practices and to promote early preventive visits to the dentists to improve oral health. Considering that dental caries is the most common disease in childhood; disabled children have an increased risk of caries compared to nondisabled children; few disabled children received effective preventive care early and that the disease represents a negative impact on the child's quality of life and family, a study on this topic is justified especially for this population.

Furthermore, notwithstanding their desire to take care of the health of their children in an adequate manner, they do not always have the 
economic and social means to put the acquired knowledge into practice (ROBLES; GROSSEMAN; BOSCO, 2010).

\section{CONCLUSION}

Oral health has an important meaning to the studied group and the practices of oral health are based on a healthy diet and the performance of brushing. Although mothers of disabled children have presented positive attitudes, in general, the observed results indicate limited knowledge about oral health. It is essential the establishment of educational interventions focused to parents, mainly mothers, of disabled children since the participation of parents can be crucial to the success of the prevention of dental caries. The results show the importance of considering the point of view of the participant as data of analysis brings a greater proximity with the reality studied. More qualitative studies should be conducted in order to collaborate with the improvement of the oral condition of disabled children.

RESUMO: O objetivo deste estudo foi conhecer os significados e as práticas de saúde bucal de dez mães de crianças com deficiência de zero a três anos de idade. Foi utilizado o método qualitativo. Os dados foram coletados por meio de entrevista semiestruturada, que foram gravadas, transcritas e analisadas pela Análise de Conteúdo Temático. Com relação aos cuidados de saúde bucal das mães, três relataram experiências difíceis e traumatizantes e três que não tiveram muito contato com o dentista na infância. Com relação às crianças, a idade da primeira visita ao dentista variou de três meses a dois anos e seis meses e o motivo desta consulta para sete crianças foi por encaminhamento médico ou da Associação de Pais e Amigos dos Excepcionais. Sete mães relataram que escovam os dentes de seus filhos pelo menos duas vezes ao dia e apenas duas citaram a importância de consultas periódicas com o dentista. Para duas mães, a saúde bucal significa ter um sorriso perfeito e para quatro ter higiene bucal. Metade das mães relacionaram a saúde bucal com a saúde geral. Todas relataram que a cárie dentária está relacionada com a dieta e com a falta de cuidado com a higiene bucal. Foi possível concluir que para este grupo de mães, a saúde bucal tem um significado importante e que as práticas de saúde bucal se baseiam em uma dieta saudável e a realização da escovação. Embora as mães de crianças com deficiência tenham apresentado atitudes positivas, em geral, os resultados indicaram um conhecimento limitado sobre saúde bucal. Os resultados evidenciam a importância de considerar o ponto de vista do participante, pois os dados de análise trazem maior proximidade com a realidade estudada. Mais estudos qualitativos devem ser conduzidos com o intuito de colaborar com a melhora da condição bucal das crianças com deficiência.

PALAVRAS-CHAVE: Saúde bucal. Mães. Criança com deficiência. Pesquisa qualitativa.

\section{REFERENCES}

AGOSTINI, B. A., MACHRY, R. V.; TEIXEIRA, C. R. S.; PIOVESAN, C.; OLIVEIRA, M. D. M.; BRESOLIN, C. R.; ARDENGHI, T. M. Self-perceived oral health influences tooth brushing in preschool children. Braz. Dent. J., Ribeirão Preto, v. 25, n. 3, p. 248-252, 2014. https://doi.org/10.1590/01036440201302426

ALYAHYA, L. Parental knowledge and practices regarding their children's oral health in Kuwait. Eur. j. paediatr. dent., Carimate, v. 17, n. 4, p. 267-273, Dec. 2016.

COSTA, A. A. I.; DELLA BONA, A.; TRENTIN, M. S. Influence of different intellectual disability levels on caries and periodontal disease. Braz. Dent. J., Ribeirão Preto, v. 27, n. 1, p. 52-5, 2016. https://doi.org/10.1590/0103-6440201600420

DOMINGUES, S. M.; CARVALHO, A. C. D.; NARVAI, P. C. Saúde bucal e cuidado odontológico: representações sociais de mães usuárias de um serviço público de saúde. Rev. bras. crescimento desenvolv. hum., v. 18, n. 1, p. 66-78, 2008. https://doi.org/10.7322/jhgd.19867 
DOS SANTOS, M. T.; MASIERO, D.; SIMIONATO, M. R. Risk factors for dental caries in children with cerebral palsy. Spec. care dentist., Bethesda, v. 22, n. 3, p. 103-7, May-Jun. 2002.

https://doi.org/10.1111/j.1754-4505.2002.tb01171.x

FIGUEIRA, T. R.; LEITE, E. C. G. Conhecimentos e práticas de pais quanto à saúde bucal e suas influências sobre os cuidados dispensados aos filhos. Pesqui. bras. odontopediatria clín. integr., João Pessoa, v. 8, n. 1, p. 87-92, jan./abr. 2008. https://doi.org/10.4034/1519.0501.2008.0081.0016

FLICK, U. A. Introduction to qualitative research. 6th ed. Sage Publications, 2019.

GAÇE, E.; KELMENDI, M.; FUSHA, E. Oral health status of children with disability living in Albania.

Mater. Sociomed., Iusgolavia, v. 26, n. 6, p. 392-4, Dec. 2014. https://doi.org/10.5455/msm.2014.26.392-394

HUEBNER, C. E. et al. Preventive dental healthcare experiences of preschool-age children with special health care needs. Spec. care dentist., Bethesda, v. 35, n. 2, p. 68-77, Mar./Apr. 2015.

https://doi.org/10.1111/scd.12084

KUMAR, G.; DHILLON, J. K.; VIGNESH, R.; GARG, A. Knowledge, attitude, and practical behavior of parents regarding their child's oral health in New Delhi. J. Indian Soc. Pedod. Prev. Dent., Chandigarh, v.37, n.1, p. 3-7, Jan./Mar. 2019. https://doi.org/10.4103/JISPPD.JISPPD_257_18

LIU, Z.; YU, D.; LUO, W.; YANG, J.; LU, J.; GAO, S.; LI, W.; ZHAO, W. Impact of oral health behaviors on dental caries in children with intellectual disabilities in Guangzhou, China. Int. j. environ. res. public health, Switzerland, v. 11, n. 10, p. 11015-27, Oct. 2014. https://doi.org/10.3390/ijerph111011015

MARCELINO, G.; PARRILHA, V. A. Educação em saúde bucal para mães de crianças especiais: um espaço para a prática dos profissionais de enfermagem. Cogitare enfermagem, Curitiba, v. 12, n. 1, p. 37-43, jan./mar. 2007. https://doi.org/10.5380/ce.v12i1.8261

MINAYO, M. C. S. Pesquisa social: teoria, método e criatividade. 29. ed. Petrópolis, RJ: Vozes, 2010.

MINAYO, M. C. S. Técnicas de análise do material qualitativo. In: MINAYO, M. C. S. O desafio do conhecimento: pesquisa qualitativa em saúde. 14. ed. São Paulo: Hucitec, 2014.

OLIVEIRA, A. C.; PORDEUS, I. A.; LUZ, C. L.; PAIVA, S. M. Mothers' perceptions concerning oral health of children and adolescents with Down syndrome: a qualitative approach. Eur. j. paediatr. dent., Carimate, v. 11, n. 1, p. 27-30, Mar. 2010.

OLIVEIRA, L. M. B. Cartilha do Censo 2010 - Pessoas com deficiência. Secretaria de Direitos Humanos da Presidência da República (SDH/PR). Secretaria Nacional de Promoção dos Direitos da Pessoa com Deficiência (SNPD). Coordenação-Geral do Sistema de Informações sobre a Pessoa com Deficiência; Brasília: SDH-PR/SNPD, 2012. 32 p.

ONU - Organização das Nações Unidas. Convenção sobre os direitos das pessoas com deficiência. Assembléia Geral das Nações Unidas. Resolução A/61/611. 2006. 33 p.

OREDUGBA, F. A.; AKINDAYOMI, Y. Oral health status and treatment needs of children and young adults attending day centre for individuals with special health care needs. BMC oral health., Melbourne, v. 8, n. 30, Oct. 2008. https://doi.org/10.1186/1472-6831-8-30

ROBLES, A. C. C. Atitude e percepção sobre saúde bucal de mães de crianças atendidas na Clínica de Odontopediatria da UFSC. Dissertação (Mestrado em Odontopediatria) - Pós-graduação em Odontologia, Universidade Federal de Santa Catarina, Florianópolis, 2005. https://doi.org/10.1590/S141381232010000800033 
ROBLES, A. C. C.; GROSSEMAN, S.; BOSCO, V. L. Práticas e significados de saúde bucal: um estudo qualitativo com mães de crianças atendidas na Universidade Federal de Santa Catarina. Ciênc. Saúde Colet., Rio de Janeiro, v. 15, n. 2, p. 3271-81, 2010.

RODRIGUES DOS SANTOS, M. T.; MASIERO, D.; NOVO, N. F.; SIMIONATO, M. R. Oral conditions in children with cerebral palsy. J. dent. child., Bethesda, v. 70, n. 1, p. 40-6, Jan./Apr. 2003.

SANTOS, M. T. B. R.; SABBAGH-HADDAD, A. Quem são os pacientes com necessidades especiais? In: CARDOSO, R J. A. Odontologia, conhecimento e arte: odontopediatria, ortodontia, ortopedia funcional dos maxilares, pacientes especiais. São Paulo: Artes Médicas, 2003. p. 261-268.

SIMIONI, L. R. G.; COMIOTTO, M. S.; REGO, D. M. Percepções maternas sobre a saúde bucal de bebês: da informação à ação. RPG rev. pos-grad., São Paulo, v. 12, n. 2, p. 163-173, abr./jun. 2005.

SINHA, N.; SINGH, B.; CHHABRA, K. G.; PATIL, S. Comparison of oral health status between children with cerebral palsy and normal children in India: a case-control study. J Indian Soc Periodontol., New Delhi v. 19, n. 1, p. 78-82, 2015. https://doi.org/10.4103/0972-124X.145800

SOARES, J.; VOLPATO, L. E. R., CATRO, P. H. S.; LAMBERT, N. A.; BORGES, A. H.; CARVALHOSA, A. A. Avaliação do conhecimento sobre saúde bucal de pais e cuidadores de crianças e adolescentes com deficiência. J Health Sci Inst., São Paulo, v. 31, n. 3, p. 239-43, 2013.

VOZZA, I.; CAVALLÈ, E.; CORRIDORE, D.; RIPARI, F.; SPOTA, A.; BRUGNOLETTI, O.; GUERRA, F. Preventive strategies in oral health for special needs patients. Ann Stomatol., Roma, v. 6, n. 3-4, p. 96-99, 2015. 